\title{
Carriage of ESBL- and AmpC-positive Enterobacteriaceae in the gastrointestinal tract of community subjects and hospitalized patients in the Czech Republic
}

\author{
Vendula Husickovaa , Luboslava Cekanovaa , Magdalena Chroma ${ }^{b}$, Miroslava Htoutou-Sedlakovaa , Kristyna Hricovaa \\ Milan Kolar ${ }^{a}$
}

\begin{abstract}
Aim. The study aimed at analyzing ESBL- and AmpC-positive Enterobacteriaceae in the gastrointestinal tracts of university hospital inpatients and persons from the Olomouc Region community, and comparing the results with data from 2007.

Methods. Bacteria were isolated from rectal swabs inoculated onto the ChromID ${ }^{\mathrm{TM}} \mathrm{ESBL}$ selective medium (bioMérieux). Production of ESBL-type beta-lactamases was confirmed by the modified double-disk synergy test and AmpC enzyme production was detected by the AmpC disk test. ESBL- and AmpC-positive isolates were subjected to basic genetic analysis aimed at detecting the $b / a_{\mathrm{TEM}}$, $b a_{\mathrm{SHN}}, b / a_{\mathrm{CTX}-\mathrm{M}}$ and $b l a_{\mathrm{AmPC}}$ genes.

Results. Over the study period (1 March 2010 - 1 May 2010), a total of 1,279 rectal swabs (70.4\% of community subjects) were analyzed on the above medium. The prevalence rates of ESBL-positive Enterobacteriaceae were $8.2 \%$ in hospitalized patients and 3.2\% in community subjects. Production of the AmpC enzyme was detected in $1.1 \%$ of bacterial isolates from the community and in one (0.3\%) hospital isolate. Among ESBL, the most frequent genes encoding enzymes were from the CTX-M-1-like genes. Detected AmpC beta-lactamases belonged to the CIT, DHA and EBC groups.

Conclusion. When compared with the year 2007, the rates of carriers of ESBL-positive bacteria increased in both hospitalized patients (from 3\% to $8 \%$ ) and community subjects (from $1 \%$ to $3 \%$ ) in 2010 . Given the fact that production of extended-spectrum beta-lactamases is clinically significant, knowing the epidemiological situation is very important for selecting adequate antibiotic therapy.
\end{abstract}

Key words: ESBL, AmpC, GIT, carriage

Received: August 29, 2011; Accepted with revison: April 4, 2012, Available online: May 25, 2012 http://dx.doi.org/10.5507/bp.2012.039

${ }^{a}$ Department of Microbiology, Faculty of Medicine and Dentistry, Palacky University Olomouc, Czech Republic 'Institute of Molecular and Translational Medicine, Faculty of Medicine and Dentistry, Palacky University Olomouc Corresponding author: Vendula Husickova, e-mail: husickova.v@seznam.cz

\section{INTRODUCTION}

At present, the Enterobacteriaceae producing broadspectrum beta-lactamases are among the bacterial pathogens that are feared. Of particular clinical importance are ESBL (extended-spectrum beta-lactamase) and AmpC enzymes capable of hydrolyzing penicillins, monobactams and cephalosporins with a broad spectrum of activity. From a clinical point of view, the danger of ESBL- and AmpC-positive Enterobacteriaceae is that they increase the risk of antibiotic treatment failure, mortality and economic costs of treatment of infections with the etiological role of bacteria ${ }^{1-4}$.

From an epidemiological perspective, the distribution of genetic types of ESBLs has changed significantly since they were first described in 1983 (ref. ${ }^{5}$ ). In the 1990s, Klebsiella pneumoniae strains producing SHV and TEM variants were most prevalent, with these strains being frequently isolated from hospital patients, especially those in intensive care units ${ }^{6}$. In recent years, the situation has changed dramatically and the main producers of ESBLs have been Escherichia coli strains producing CTX-M-type beta-lactamases.
Recently, the numbers of ESBL-positive bacteria isolated from clinical material of both patients hospitalized in general hospital wards and those in the community have increased ${ }^{7}$. In their study, Valverde et al. compared the prevalence of ESBLs in the gastrointestinal tract (GIT) of both hospital and community patients in 1991 and 2003. They reported that over the twelve years, the prevalence of ESBLs has increased dramatically, from $0.3 \%$ in inpatients and $0.7 \%$ in outpatients to $11.8 \%$ and $5.5 \%$, respectively. The study also found ESBL prevalence in healthy volunteers to be $3.7 \%$ in $2003\left(\right.$ (ref. $^{8}$ ).

Colonization with ESBL-positive isolates is considered to be a risk factor. The higher proportion of ESBL carriers in the community increases the risk that more individuals will become carriers due to interhuman transmission. It also expands the resistance gene pool and thus makes the acquisition of resistance genes by sensitive bacteria faster.

With the rising number of ESBL-positive bacterial strains, the rates of clinically significant isolates producing AmpC-type beta-lactamases also increase. Qin et al. showed an increase in the prevalence of AmpC-positive isolates in hospitalized paediatric patients from $0.1 \%$ in $1999-2001$ to $0.9 \%$ in $2005-2007$ (ref. ${ }^{9}$ ). A rise in the inci- 
dence of infection-related AmpC-positive Escherichia coli strains was noted in a 3-year Canadian prospective study involving not only hospital but mostly (83\%) community isolates ${ }^{10}$.

Compared to ESBL carriage in the GIT of community subjects, the number of studies focused on AmpCproducing bacterial strains is much smaller. Hammerum et al. reported $4 \%$ prevalence of AmpC-positive strains in rectal swabs from healthy persons ${ }^{11}$. AmpC-producing Enterobacteriaceae in community subjects were also detected in a study by Čekanová et al. ${ }^{12}$.

The presented study aimed at determining the prevalence of ESBL- and AmpC-positive Enterobacteriaceae in the GIT of subjects in both the hospital and community settings and comparing changes in their epidemiology with data from an earlier study performed in the same area in 2007.

\section{MATERIAL AND METHODS}

\section{Bacterial strains}

Bacteria were isolated from rectal swabs obtained from ambulatory patients from community living in the Olomouc Region and from patients in the University Hospital Olomouc with the identical catchment area between 1 March 2010 and 1 May 2010. From each person, only one rectal swab was processed. The swabs were inoculated onto the selective ChromID ${ }^{\mathrm{TM}}$ ESBL agar (bioMérieux). Grown colonies were identified using standard microbiology techniques as well the Phoenix automated system (Becton, Dickinson and Company). Individual iso- lates were placed in a deep freezer and stored at $-80{ }^{\circ} \mathrm{C}$ using the ITEST Kryobanka B (ITEST plus s.r.o.).

\section{Phenotypic detection of ESBL and AmpC}

All isolated Enterobacteriaceae were subjected to phenotypic analysis to detect ESBL and AmpC enzyme production. Phenopytic detection of ESBLs was performed by the modified double-disk synergy test (mDDST) $\left(\right.$ ref. ${ }^{13,14}$ ). AmpC production was detected by the AmpC disk test with 3-aminophenylboronic acid ${ }^{15}$.

\section{PCR-RFLP}

Results of phenotypic analysis were verified by polymerase chain reaction (PCR) detecting genes encoding the relevant beta-lactamases. Isolated bacteria were inoculated onto Mueller-Hinton agar (Trios, spol. s r.o.) and incubated at $37^{\circ} \mathrm{C}$ for $18 \mathrm{~h}$. DNA for the reaction was obtained from bacterial cell suspension prepared by mixing 1-2 freshly grown colonies with $100 \mu \mathrm{L}$ of distilled water, heating to $95^{\circ} \mathrm{C}$ for $10 \mathrm{~min}$ and subsequently centrifuged at $13000 \times \mathrm{g}$ for $2 \mathrm{~min}$. In the case of ESBL-positive isolates, the resulting supernatant was used as a template for PCR with specific primers for detecting the $b l a_{\mathrm{TEM}}$, $b l a_{\mathrm{SHV}}$ and $b l a_{\text {СтХ-M }}$ genes $^{16-19}$. DNA from bacteria with the AmpC phenotype was subjected to multiplex PCR with primers specific for detecting genes encoding the relevant beta-lactamases ${ }^{20}$. The resulting PCR products were electrophoretically separated in $1.5 \%$ agarose gel stained with ethidium bromide ( $\left.1 \mu \mathrm{g} \cdot \mathrm{mL}^{-1}\right)$ and documented using an imaging device.

In isolates with positive PCR detecting the $b l a_{\mathrm{TEM}}$ or bla $_{\mathrm{SHV}}$ genes, restriction analysis was performed. TEM

Table 1. Overview of ESBL- and AmpC-positive isolates and differences in species distribution of these isolates in hospital and community settings.

\begin{tabular}{|c|c|c|c|c|c|c|c|c|c|c|}
\hline & \multicolumn{2}{|c|}{$\begin{array}{c}\text { Total number of } \\
\text { isolates }\end{array}$} & \multicolumn{4}{|c|}{ Hospitalized patients } & \multicolumn{4}{|c|}{ Community subjects } \\
\hline species & $\begin{array}{l}\text { ESBL+ } \\
\text { (count) }\end{array}$ & $\begin{array}{l}\text { AmpC+ } \\
\text { (count) }\end{array}$ & $\begin{array}{l}\text { ESBL+ } \\
\text { (count) }\end{array}$ & $\begin{array}{c}\text { ESBL+ } \\
(\%)\end{array}$ & $\begin{array}{l}\text { AmpC+ } \\
\text { (count) }\end{array}$ & $\begin{array}{c}\mathrm{AmpC}+ \\
(\%)\end{array}$ & $\begin{array}{l}\text { ESBL+ } \\
\text { (count) }\end{array}$ & $\begin{array}{c}\text { ESBL+ } \\
(\%)\end{array}$ & $\begin{array}{l}\text { AmpC+ } \\
\text { (count) }\end{array}$ & $\begin{array}{c}\text { AmpC+ } \\
(\%)\end{array}$ \\
\hline $\begin{array}{l}\text { Citrobacter } \\
\text { freundii }\end{array}$ & 0 & 3 & 0 & 0.0 & 0 & 0.0 & 0 & 0.0 & 3 & 30.0 \\
\hline $\begin{array}{l}\text { Citrobacter } \\
\text { werkmanii }\end{array}$ & 0 & 1 & 0 & 0.0 & 0 & 0.0 & 0 & 0.0 & 1 & 10.0 \\
\hline $\begin{array}{l}\text { Enterobacter } \\
\text { aerogenes }\end{array}$ & 1 & 0 & 1 & 3.2 & 0 & 0.0 & 0 & 0.0 & 0 & 0.0 \\
\hline $\begin{array}{l}\text { Enterobacter } \\
\text { cloacae }\end{array}$ & 0 & 2 & 0 & 0.0 & 0 & 0.0 & 0 & 0.0 & 2 & 20.0 \\
\hline $\begin{array}{l}\text { Escherichia } \\
\text { coli }\end{array}$ & 35 & 3 & 9 & 29.0 & 0 & 0.0 & 26 & 89.7 & 3 & 30.0 \\
\hline $\begin{array}{l}\text { Klebsiella } \\
\text { oxytoca }\end{array}$ & 3 & 1 & 2 & 6.5 & 1 & 100.0 & 1 & 3.4 & 0 & 0.0 \\
\hline $\begin{array}{l}\text { Klebsiella } \\
\text { pneumoniae }\end{array}$ & 21 & 0 & 19 & 61.3 & 0 & 0.0 & 2 & 6.9 & 0 & 0.0 \\
\hline $\begin{array}{l}\text { Morganella } \\
\text { morganii }\end{array}$ & 0 & 1 & 0 & 0.0 & 0 & 0.0 & 0 & 0.0 & 1 & 10.0 \\
\hline Total & 60 & 11 & 31 & 100.0 & 1 & 100.0 & 29 & 100.0 & 10 & 100.0 \\
\hline
\end{tabular}


Table 2. Genetic analysis of ESBL-positive Enterobacteriaceae.

\begin{tabular}{lcccc}
\hline \multirow{2}{*}{ bla genes } & \multicolumn{4}{c}{ Number of isolates } \\
\cline { 2 - 5 } & \multicolumn{2}{c}{ Escherichia coli } & Klebsiella pneumoniae \\
\cline { 2 - 5 } & hospital & community & hospital & community \\
\hline CTX-M-1-like & 5 & 9 & 0 & 0 \\
CTX-M-9-like & 1 & 8 & 0 & 0 \\
SHV ESBL & 0 & 0 & 1 & 0 \\
CTX-M-1-like + TEM & 3 & 3 & 0 & 0 \\
CTX-M-9-like + TEM & 0 & 6 & 0 & 0 \\
CTX-M-1-like + SHV + TEM & 0 & 0 & 18 & 2 \\
\hline
\end{tabular}

products were cleaved by the MseI, Sau3AI, MspI and $H p h I$ enzymes (New England Biolabs) (detection of the most frequent mutations at positions 104, 164, 238 and 240 responsible for extending the spectrum of effectiveness in TEM-type beta-lactamases) and the resulting DNA fragments were separated in $2.5 \%(\mathrm{w} / \mathrm{v})$ agarose gel stained with ethidium bromide $\left(1 \mu \mathrm{g} . \mathrm{mL}^{-1}\right)\left(\right.$ ref. $\left.{ }^{16}\right)$. For restriction of SHV products, the NheI, DdeI and SacII (New England Biolabs) endonucleases were used to detect potential mutations at positions 238, 35 and 179 most frequently responsible for the development of the ESBL phenotype in SHV-type beta-lactamases ${ }^{17}$. The cleaved DNA fragments were divided in $2 \%(\mathrm{w} / \mathrm{v})$ agarose gel stained with ethidium bromide $\left(1 \mu \mathrm{g} \cdot \mathrm{mL}^{-1}\right)$.

\section{PFGE}

DNA was isolated from a bacterial culture incubated at $37^{\circ} \mathrm{C}$ for $16 \mathrm{~h}$ in $20 \mathrm{~mL}$ of Mueller-Hinton broth. The cells were centrifuged at $4000 \times g$ for $10 \mathrm{~min}$ and the pellet was washed three times with washing solution $(10 \mathrm{mM}$ Tris/HCl, 10 mM EDTA, 10 mM EGTA, 1 M NaCl; $\mathrm{pH}$ 7.5). Afterwards, the bacteria were diluted with the washing solution for optical density of 0.2-0.3 at $600 \mathrm{~nm}$ and $10 \mathrm{~mL}$ of this suspension were centrifuged. The cells were resuspended in $100 \mu \mathrm{L}$ of washing solution, mixed with the same amount of $2 \%$ low melting point agarose (BioRad Laboratories) and pipetted into a block former. The prepared agarose blocks were transferred into $1 \mathrm{~mL}$ of lysing solution ( $6 \mathrm{mM}$ Tris/HCl, $100 \mathrm{mM}$ EDTA, $1 \mathrm{M}$ $\mathrm{NaCl}, 0.5 \%$ BRIJ, $0.2 \%$ sodium deoxycholate, $0.5 \%$ lauryl sarcosine; $\mathrm{pH} 7.6)$ with lysozyme $\left(0.5 \mathrm{mg} . \mathrm{mL}^{-1}\right)$ and incubated at $37^{\circ} \mathrm{C}$ overnight. Then the blocks were transferred to $1 \mathrm{~mL}$ of deproteinization solution with proteinase $\mathrm{K}$ $\left(0.5 \mathrm{mg} \cdot \mathrm{mL}^{-1}\right)$ and incubated at $55^{\circ} \mathrm{C}$ for $24 \mathrm{~h}$. Proteinase $\mathrm{K}$ (Finnzymes) was inactivated by washing the blocks in $10 \mathrm{~mL}$ of TE buffer (10mM Tris/Hcl, 1mM EDTA; $\mathrm{pH}$ 7.8) at $4{ }^{\circ} \mathrm{C}$ for $24 \mathrm{~h}$. From each block, a thin slice was cut and transferred into $50 \mu \mathrm{L}$ of restriction solution with $15 \mathrm{U}$ of the $\mathrm{XbaI}$ restriction enzyme (Fermentas) and incubated at $37{ }^{\circ} \mathrm{C}$ for $24 \mathrm{~h}$. The obtained DNA fragments were separated by pulsed field gel electrophoresis (PFGE) in $1.2 \%$ agarose gel at $6 \mathrm{~V} . \mathrm{cm}^{-1}$ and pulse times of $2-35 \mathrm{~s}$ for $24 \mathrm{~h}$. After staining of the gel with ethidium bromide, the resulting restriction profiles were documented using an imaging device and compared by the GelCompar II software (Applied Maths, Kortrijk, Belgium).

\section{Statistical analysis}

Statistical significance for comparison of proportions was calculated by the chi-square test (a $P$ value $<0.05$ was considered statistically significant).

\section{RESULTS}

In the study period of 1 March 2010 to 1 May 2010, a total of 378 rectal swabs from the University Hospital Olomouc inpatients and 901 rectal swabs from persons in the Olomouc Region community were analyzed. Growth on the chromID ${ }^{\mathrm{TM}}$ ESBL selective agar was observed in 76 of the 1,279 samples. Subsequent phenotypic detection confirmed 60 ESBL- and 11 AmpC-positive isolates of the family Enterobacteriaceae. The most prevalent ESBL-positive isolates were Escherichia coli and Klebsiella pneumoniae, accounting for $93.3 \%$. The most frequently isolated AmpC-positive bacteria were Escherichia coli and Citrobacter freundii. Detailed distribution of species is shown in Table 1.

Comparison of the prevalence of ESBL- and AmpCpositive isolates in hospital and community settings showed significant differences in both prevalence and species distribution between the two groups. The results are summarized in Table 1. The obtained data revealed $8.2 \%$ prevalence of ESBL-positive isolates in the University Hospital Olomouc inpatients. In subjects from the community, a total of 29 ESBL-positive strains were isolated, accounting for $3.2 \%$. In comparison with data from 2007 , the rates of patient fecal carriage significantly increased from $2.6 \%$ (14/546) hospitalized patients in 2007 to $8.2 \%$ $(31 / 378)$ in $2010(P<0.001)$ and $1.2 \%(7 / 579)$ community subjects to $3.2 \%(29 / 901)(P<0.05)$, respectively. Out of 11 AmpC-positive isolates, ten were detected in community subjects, a prevalence of $1.1 \%$. More than one half of ESBL-positive hospital isolates were Klebsiella 
Fig. 1. Dendrogram of ESBL-positive strains of Escherichia coli.

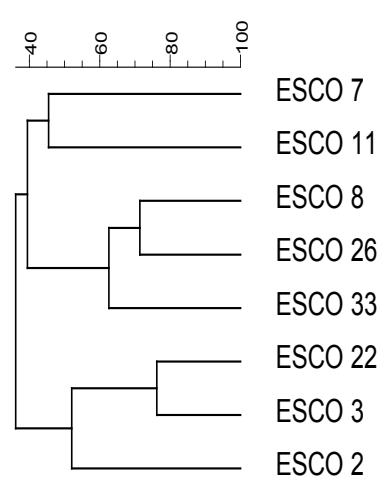

Legend: horizontal axis - similarity of bacterial isolates in \%; vertical axis - isolate codes

Fig. 2. Dendrogram of ESBL-positive strains of Klebsiella pneumoniae.

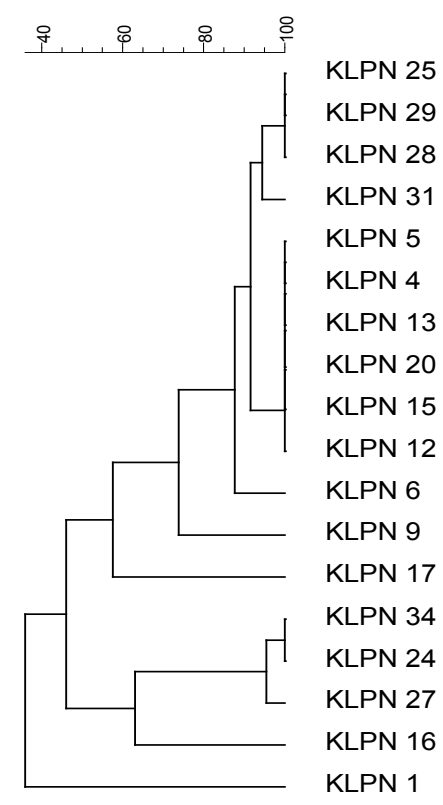

Legend: horizontal axis - similarity of bacterial isolates in \%; vertical axis - isolate codes

pneumoniae strains (61.3\%). In the community, the most prevalent isolates were Escherichia coli (89.7\%).

Genetic analysis of 60 bacterial isolates with the ESBL phenotype revealed the presence of the $b l a_{\text {CTX-M }}$ gene in 57 isolates ( 29 community isolates/28 hospital isolates). The $b l a_{\mathrm{SHV}}$ gene was detected in 22 cases (20/2) and the $b l a_{\mathrm{TEM}}$ gene in 35 strains (23/12). Distribution of individual bla genes in Escherichia coli and Klebsiella pneumoniae (a total of 56 isolates) is shown in Table 2. Of the four remaining ESBL-positive bacteria, PCR confirmed presence of the $b l a_{\mathrm{SHV}}, b l a_{\mathrm{TEM}}$ and $b l a_{\mathrm{CTX}-\mathrm{M}-1-\mathrm{like}}$ genes in a strain of Enterobacter aerogenes. In one Klebsiella oxytoca strain, the $b l a_{\text {CTX-M-1-1ike }}$ and $b l a_{\text {TЕM }}$ genes were also detected. In two strains of Klebsiella oxytoca, the ESBL phenotype was not confirmed by PCR.

Restriction analysis of PCR products aimed at detecting the most frequent mutations responsible for extending the spectrum of effectiveness of relevant beta-lactamases did not reveal, in the case of TEM products, any of the changes in any isolate. In SHV products, a mutation associated with the extended spectrum of effectiveness was detected by restriction analysis in two Klebsiella pneumoniae strains. In both isolates, the mutation was at position 35 .

Detection of AmpC beta-lactamases by multiplex PCR confirmed the AmpC phenotype in 9 out of 11 isolates. In each isolate, only one PCR product was detected. Most frequently in six strains (3 Citrobacter freundii, 1 Citrobacter werkmanii, 2 Escherichia coli), a 462-bp-long amplicon was detected, corresponding to CIT beta-lactamases. In two cases (1 Klebsiella oxytoca, 1 Morganella morganii), a DHA-type PCR product and in one strain (Enterobacter cloacae), an EBC-type product were noted. Multiplex PCR was negative in two isolates (1 Enterobacter cloacae, 1 Escherichia coli).

Similar or identical strains were analyzed by PFGE in 30 out of 31 ESBL-positive hospital isolates. An isolate of Enterobacter aerogenes was excluded, being the only one of its kind. The results of comparison are demonstrated as dendrograms in Fig. 1 and 2. Out of 9 Escherichia coli isolates, 8 strains had unique restriction profiles. In one case, DNA repeatedly failed to be isolated in adequate quality. By contrast, several completely identical Klebsiella pneumoniae isolates were detected and several isolates were found to have a very similar restriction profile, very likely corresponding to a single genetic change. Identical profiles were observed in 1 group of six, 1 group of three and 1 group of two Klebsiella pneumoniae isolates. Given the fact that in all cases, identical strains were isolated from different patients, the situation is suggestive of clonal spread. As well as in Escherichia coli, a restriction profile sufficient for analysis could not been repeatedly obtained in one Klebsiella pneumoniae strain. Two Klebsiella oxytoca strains were genetically different.

\section{DISCUSSION}

The prevalence of ESBL-producing isolates is a global problem. Compared with other continents, the ESBL prevalence in Europe is higher than in the USA but lower than in Asia or South America ${ }^{7}$. Carriage of these strains is also of great importance. Livermore and Paterson stated that in the case of higher rates of infections caused by ESBL-positive strains in a particular ward, nearly $70 \%$ of patients had their gastrointestinal tract (GIT) colonized by these strains ${ }^{21}$.

Castillo et al. studied gastrointestinal colonization by ESBL-positive strains in both hospitalized and community subjects. Their results revealed an increase in the prevalence of ESBL-producing strains in both patients and community subjects, from $3 \%$ and $2 \%$, respectively, 
in 2002 to $8 \%$ and $7 \%$, respectively, in 2004 . In both study periods, Escherichia coli was the most prevalent species ${ }^{22}$. In the Czech Republic, a study on colonization of the GIT by bacteria producing ESBL enzymes was carried out in 2007. The results showed 3\% prevalence in hospitalized patients and Escherichia coli prevailed (57\%) (ref. ${ }^{12}$ ). When compared with that study, our current results show an increase in the prevalence of ESBL-positive Enterobacteriaceae in the GIT of hospitalized patients (8\%). Species distribution also changed, with Klebsiella pneumoniae being more prevalent among hospital ESBLpositive isolates $(56 \%)$.

The increasing prevalence of ESBL-positive Enterobacteriaceae in the GIT of community subjects has also been reported in other European countries such as Spain and Great Britain ${ }^{8,23}$. Most frequently, Escherichia coli isolates producing CTX-M beta-lactamases are identified $^{24,25}$. In their study, Valverde et al. reported $4 \%$ prevalence of ESBL-positive Enterobacteriaceae in the stools of healthy volunteers in Spain in 2003. All these strains were classified as Escherichia coli ${ }^{8}$. The authors of another Spanish study published in 2007 focused on assessing the prevalence of GIT colonization by ESBL-positive Enterobacteriaceae in a group of healthy persons and found $7 \%$ prevalence, with bacteria producing CTX-M enzymes being most frequent ${ }^{26}$. Janvier et al. compared the prevalence of ESBL-positive Enterobacteriaceae in asymptomatic young subjects in the community over a period of 10 years (1999-2009) to detect an increase from $0 \%$ to $2 \%$. Most frequently, enzymes from the CTX-M-1 group were detected ${ }^{27}$.

In the Czech Republic, a 1\% prevalence of ESBLpositive Enterobacteriaceae in the GIT of community subjects was reported in 2007. In all cases, the species was Escherichia coli. The CTX-M-15, CTX-M-1 and CTX-M-9like enzymes were detected ${ }^{12}$. Our current study showed an increase in ESBL-carriage in the GIT of community subjects to $3 \%$. However, this is still less than the average European rates. As compared with 2007, species distribution is more varied although Escherichia coli remains the most frequent (90\%). The genetic background is quite similar, with CTX-M-1-like and CTX-M-9-like types prevailing.

In contrast to ESBL enzymes, carriage of AmpCpositive bacterial enzymes have not been studied much. Kaneko et al. reported an Escherichia coli isolate producing AmpC beta-lactamase of the CMY-2 type from the CIT group in a healthy medical student. They suggested that both constitutive and inducible AmpC betalactamases may extensively spread in the community ${ }^{28}$. In 2008, carriage of AmpC beta-lactamases in the GIT was detected in nearly $4 \%$ of healthy Danish army recruits. The types were CMY-2 and CMY-34. The same group was also found to carry ESBL-positive Enterobacteriaceae ${ }^{11}$.

In the Czech Republic, the prevalence of AmpCpositive bacteria in the GIT of community subjects was reported to be $1 \%$ in 2007 (ref. ${ }^{12}$ ). Our current study found the same prevalence rate of AmpC-positive Enterobacteriaceae (1\%). However, there was a difference in species distribution of AmpC-positive isolates, with Escherichia coli and Citrobacter freundii being most prevalent in the current study. AmpC beta-lactamases of the DHA, CIT and EBC types were detected. An interesting finding of this current study is the very low rate of AmpCpositive isolates in hospitalized patients as compared with community subjects. Production of an AmpC enzyme was detected in a single hospital isolate.

An important result of this study is detection of a high number of ESBL-positive isolates of Klebsiella pneumoniae in which PFGE identified identical or very similar restriction profiles. This fact suggests clonal spread of the strain among hospitalized patients and deserves further attention. A new study may follow that would aid in revealing the sources and modes of transmission of the strains. The results might contribute to the limitation of further spread.

Colonization of the GIT by ESBL- and AmpCproducing Enterobacteriaceae increases the risk of infection due to these opportunistic pathogens as well as the possibility that mobile elements carrying resistance genes will be disseminated into a broad community. Therefore, detection and control of the community reservoir is extremely important.

\section{ACKNOWLEDGEMENT}

Supported by grant projects IGA 9950-3, VVZ MSM6198959223 and LF_2011_002. Infrastructural part of this project (Institute of Molecular and Translational Medicine) was supported from the Operational Programme Research and Development for Innovations (project CZ.1.05/2.1.00/01.0030).

\section{REFERENCES}

1. Pai H, Kang Cl, Byeon JH, Lee KD, Park WB, Kim HB, Kim EC, Oh MD, Choe KW. Epidemiology and clinical features of bloodstream infections caused by AmpC-type-beta-lactamase-producing Klebsiella pneumoniae. Antimicrob Agents Chemother 2004;48:3720-8.

2. Paterson DL, Bonomo RA. Extended-spectrum $\beta$-lactamases: A clinical update. Clin Microbiol Rev 2005;18:657-86.

3. Tumbarello M, Sanguinetti M, Montuori E, Trecarichi EM, Posteraro B, Fiori B, Citton R, D'Inzeo T, Fadda G, Cauda R, Spanu T. Predictors of mortality in patients with bloodstream infections caused by extended-spectrum-ß-lactamase-producing Enterobacteriaceae: importance of inadequate initial antimicrobial treatment. Antimicrob Agents Chemother 2007;51:1987-94.

4. Schwaber MJ, Navon-Venezia S, Kaye KS, Ben-Ami R, Schwartz $D$, Carmeli Y. Clinical and economic impact of bacteremia with extended-spectrum- $\beta$-lactamase-producing Enterobacteriaceae. Antimicrob Agents Chemother 2006;50:1257-62.

5. Knothe H, Shah P, Krcmery V, Antal M, Mitsuhashi S. Transferable resistance to cefotaxime, cefoxitin, cefamandole and cefuroxime in clinical isolates of Klebsiella pneumoniae and Serratia marcescens. Infection 1983;11:315-7.

6. Coque TM, Baquero F, Canton R. Increasing prevalence of ESBL-producing Enterobacteriaceae in Europe. Euro Surveill 2008;13(47):pii=19044. Available online: http://www.eurosurveillance.org/ViewArticle.aspx?Articleld=19044

7. Cantón R, Novais A, Valverde A, Machado E, Peixe L, Baquero F, Coque TM. Prevalence and spread of extended-spectrum $\beta$-lactamase- 
producing Enterobacteriaceae in Europe. Clin Microbiol Infect 2008;14(Suppl. 1):144-53.

8. Valverde A, Coque TM, Sanchez-Moreno MP, Rollán A, Baquero F Cantón R. Dramatic increase in prevalence of fecal carriage of extended- spectrum beta-lactamase-producing Enterobacteriaceae during nonoutbreak situations in Spain. J Clin Microbiol 2004;42:4769-75.

9. Qin X, Zerr DM, Weissman SJ, Englund JA, Denno DM, Klein EJ, Tarr PI, Kwong J, Stapp JR, Tulloch LG, Galanakis E. Prevalence and mechanisms of broad-spectrum $\beta$-lactam resistance in Enterobacteriaceae: a children's hospital experience. Antimicrob Agents Chemother 2008;52:3909-14.

10. Pitout JD, Gregson DB, Church DL, Laupland KB. Populationbased laboratory surveillance for AmpC $\beta$-lactamase-producing Escherichia coli, Calgary. Emerg Infect Dis 2007;13:443-8.

11. Hammerum AM, Lester CH, Jakobsen L, Porsbo LJ. Faecal carriage of extended-spectrum $\beta$-lactamase-producing and AmpC $\beta$-lactamase-producing bacteria among Danish army recruits. Clin Microbiol Infect 2011;17:566-8.

12. Cekanova L, Kolar M, Chroma M, Sauer P, Sedlácková M, Koukalová D Prevalence of ESBL-positive bacteria in the community in the Czech Republic. Med Sci Monit 2009;15(7):BR202-6.

13. Jarlier V, Nicolas MH, Fournier G, Philippon A. Extended broadspectrum $\beta$-lactamases conferring transferable resistance to newer $\beta$-lactam agents in Enterobacteriaceae: hospital prevalence and susceptibility patterns. Rev Infect Dis 1988;10:867-78.

14. Koláŕ M. Clinical significance of broad-spectrum ß-lactamases and experience with their identification in microbiological practice. Klin Mikrobiol Inf Lék 2007;13(5): 195-205.

15. Yagi T, Wachino J, Kurokawa H, Suzuki S, Yamane K, Doi Y, Shibata N, Kato H, Shibayama K, Arakawa Y. Practical methods using boronic acid compounds for identification of class $C \beta$-lactamase-producing Klebsiella pneumoniae and Escherichia coli. J Clin Microbio 2005:43:2551-8

16. Arlet $G$, Brami G, Décrè $D$, Flippo $A$, Gaillot $O$, Lagrange $P H$ Philippon A. Molecular characterisation by PCR-restriction fragment length polymorphism of TEM $\beta$-lactamases. FEMS Microbiol Lett 1995;134:203-8.

17. Chanawong A, M'Zali F, Heritage J, Lulitanond, A, Hawkey PM Characterisation of extended-spectrum $\beta$-lactamases of the SHV family using a combination of PCR-single strand conformational polymorphism (PCR-SSCP) and PCR-restriction fragment length polymorphism (PCR-RFLP). FEMS Microbiol Lett 2000;184:85-9.

18. Pagani L, Dell'Amico E, Migliavacca R, D'Andrea MM, Giacobone
E, Amicosante G, Romero E, Rossolini GM. Multiple CTX-M-type extended-spectrum $\beta$-lactamases in nosocomial isolates of Enterobacteriaceae from a hospital in northern Italy. J Clin Microbiol 2003:41:4264-9.

19. Minarini LA, Gales AC, Palazzo IC, Darini AL. Prevalence of community-occuring extended spectrum $\beta$-lactamase-producing Enterobacteriaceae in Brazil. Curr Microbiol 2007;54(5):335-41.

20. Pérez-Pérez FJ, Hanson ND. Detection of plasmid-mediated AmpC $\beta$-lactamase genes in clinical isolates by using multiplex PCR. J Clin Microbiol 2002:40:2153-62

21. Livermore DM, Paterson DL. Pocket guide to extended spectrum B-lactamases in resistance. Current Medicine Group Ltd, Spain, 2006.

22. Castillo García FJ, Seral García C, Pardos De la Gandara M, Millán Lou MI, Pitart Ferré C. Prevalence of fecal carriage of ESBL-producing Enterobacteriaceae in hospitalized and ambulatory patients during two non-outbreak periods. Eur J Clin Microbiol Infect Dis 2007;26:778.

23. Munday CJ, Whitehead GM, Todd NJ, Campbell M, Hawkey PM. Predominance and genetic diversity of community and hospital acquired CTX-M extended-spectrum B-lactamases in York, UK. J Antimicrob Chemother 2004;54:628-33.

24. Rodríguez-Baño J, López-Cerero L, Navarro MD, Díaz de Alba P, Pascual A. Faecal carriage of extended-spectrum beta-lactamaseproducing Escherichia coli: prevalence, risk factors and molecular epidemiology. J Antimicrob Chemother 2008;62:1142-9.

25. Woodford N, Ward ME, Kaufmann ME, Turton J, Fagan EJ, James D, Johnson AP, Pike R, Warner M, Cheasty T, Pearson A, Harry S, Leach $\mathrm{JB}$, Loughrey A, Lowes JA, Warren RE, Livermore DM. Community and hospital spread of Escherichia coli producing CTX-M extended-spectrum $\beta$-lactamases in the UK. J Antimicrob Chemother 2004:54:73543.

26. Vinue L, Saenz Y, Martinez S, Somalo S, Moreno MA, Torres $C$, Zarazaga M. Prevalence and diversity of extended-spectrum betalactamases in faecal Escherichia coli isolates from healthy humans in Spain. Clin Microbiol Infect 2009;15:954-7.

27. Janvier F, Mérens A, Delaune D, Soler C, Cavallo JD. Portage digestif d'entérobactéries résistantes aux céphalosporines de troisième génération dans une population d'adultes jeunes asymptomatiques: évolution entre 1999 et 2009. Pathol Biol (Paris) 2010. doi: 10.1016/j. patbio.2010.07.012

28. Kaneko K, Sato Y, Tokunaga S, Tamaki SK, Okamoto R, Inoue M. AmpC beta-lactamase-mediated cefpodoxime-resistant Escherichia coli isolated from faecal samples of healthy volunteers. J Antimicrob Chemother 2006;57:369-71. 